\title{
High Performance HRM and Establishment Performance in Pakistan: An Empirical Analysis
}

DOI:

10.1108/ER-05-2014-0044

\section{Document Version}

Accepted author manuscript

Link to publication record in Manchester Research Explorer

\section{Citation for published version (APA):}

Ahmad, M., \& Allen, M. M. C. (2015). High Performance HRM and Establishment Performance in Pakistan: An Empirical Analysis. Employee Relations, 37(5), 506-524. https://doi.org/10.1108/ER-05-2014-0044

\section{Published in:}

Employee Relations

\section{Citing this paper}

Please note that where the full-text provided on Manchester Research Explorer is the Author Accepted Manuscript or Proof version this may differ from the final Published version. If citing, it is advised that you check and use the publisher's definitive version.

\section{General rights}

Copyright and moral rights for the publications made accessible in the Research Explorer are retained by the authors and/or other copyright owners and it is a condition of accessing publications that users recognise and abide by the legal requirements associated with these rights.

\section{Takedown policy}

If you believe that this document breaches copyright please refer to the University of Manchester's Takedown Procedures [http://man.ac.uk/04Y6Bo] or contact uml.scholarlycommunications@manchester.ac.uk providing relevant details, so we can investigate your claim.

\section{OPEN ACCESS}


$\underline{\text { High Performance HRM and Establishment Performance in Pakistan: An Empirical Analysis }}$

Mansoor Ahmad

Matthew M.C. Allen

\section{$\underline{\text { Abstract }}$}

Purpose: Despite a growing literature on human resource management in emerging economies, evidence from Pakistan is limited. There is scant information on both the HR practices that indigenous workplaces adopt and their associations with HR-related outcomes. This paper fills that gap by examining whether universalistic assumptions about the applicability of 'high performance' HR practices are valid in Pakistan, a country with religious values and organizational traditions that differ to those in the West.

Design/methodology/approach: This study draws on the, to date, most comprehensive survey of indigenous establishments in Pakistan. The data were analysed using logistic regressions.

Findings: Workplaces, in general, adopt several 'high performance' HR practices, such as extensive training, career breaks, rigorous pre-employment candidate assessment, and the sharing of strategic information with employees. Attitude surveys and the provision of training in a variety of jobs to non-managerial employees are consistently associated with better HR-related outcomes (absenteeism, quit rates, and labour productivity). Overall, the paper finds some limited support for the applicability and efficacy of high-performance HRM practices in Pakistan. Such practices conform to Islamic principles. The results also indicate, however, that cultural traits play a role in how those practices are implemented. 
Social and practical implications: Increased adoption of certain HR practices by establishments in Pakistan may also help to improve the working conditions and employment prospects of employees and may also ameliorate the country's sluggish economic growth rates.

Originality/value: HRM in Pakistani establishments has received relatively scant attention. Existing research either focuses on a relatively small number of firms, assesses HR in MNC subsidiaries, or examines a limited range of HR practices. Understanding the HR practices that are (and are not) adopted and their associations with performance outcomes will not just enhance our knowledge of HR in emerging economies, but also provide insights into how establishment performance and economic growth rates might be improved.

Keywords: 'high performance' HR practices, absenteeism, quit rates, productivity, emerging economies, Pakistan

Article Classification: Research paper 


\section{Introduction}

Research on the links between 'high-performance' HR practices and organizational performance is an important strand of the literature (Guest et al., 2003; Huselid, 1995; Ichniowski et al., 1997; Wood, 1999; Wood and de Menezes, 1998, 2008). Much of this work examines firms in developed economies. Studies that examine HRM in developing economies tend to focus on MNC subsidiaries at the expense of examining HR policies in indigenous (local) firms (Budhwar and Debrah, 2001, 2009).

There has, however, recently been an upsurge in interest in the HR practices of indigenous firms in developing economies, including those in the Indian sub-continent (Chand and Katou, 2007; Chandrakumara, 2007; Raman et al., 2007) and the Middle East (Budhwar and Mellahi, 2006). Increased international economic competition, a lack of awareness and understanding of HR practices in indigenous firms, and a desire to assess if high-performance HR practices that emerged in Western countries can be applied in developing economies lie behind these studies (Budhwar and Debrah, 2009; Ramdani et al., 2014).

Very little is known, however, about, first, the human resource practices of Pakistani establishments (or business units) and, second, the links between HRM and establishment performance there (Budhwar and Singh, 2007; Chaudhry 2013; Debrah and Budhwar, 2001; Khilji, 2001, 2002; Tayeb, 1997; Yasmin, 2008). Previous research either focuses on a relatively small number of firms, whose findings cannot be generalized (Chaudhry, 2013; Khilji, 2001); assesses HR in MNC subsidiaries (Chaudhry, 2013; Khilji, 2002); or examines a limited range of HR practices (Yasmin, 2008).

Pakistan is a particularly interesting country to study the associations between highperformance HR practices and establishment performance for three main reasons. First, Pakistan is characterized by collectivism, high power distance (Mangi et al., 2012), and high 
uncertainty avoidance (Islam, 2005) that largely account for organizational practices, such as nepotism, centralization, and corruption, that some research identifies as traits of Pakistani organizations (Islam, 2005; Khilji, 2002). These characteristics could, as is discussed below, hinder both the adoption and efficacy of high-performance workplace practices.

Second, the role of religion in management, although largely ignored until recently (Mellahi and Budhwar, 2010), is important in Pakistan (Khilji, 2002; Tayeb, 1997), as it is in other emerging economies with Muslim majorities (Ali, 2010; Branine and Pollard, 2010; Hashim, 2010). Even though the philosophical foundations of the Islamic model of HRM differ to those of Western thought (Ali, 2010), they do not contradict the principles of highperformance workplace practices that came to prominence, and have evolved, in the US and the UK (Ali, 2010). Indeed, in many instances, Islamic principles of HRM converge with those of high-performance HRM practices (Abuznaid, 2006; Ali, 2010; Branine and Pollard, 2010; Budhwar and Mellahi, 2007; Mellahi and Budhwar, 2010). The role of religion may, therefore, encourage the use and efficacy of high-performance HR practices in indigenous establishments.

Finally, low labour productivity is one of the causes of sluggish economic growth in Pakistan (World Bank 2013). HR practices that improve employees' skills and increase productivity may also ameliorate social and working conditions, key concerns for Pakistani policy makers (NAVTEC, 2009; World Bank, 2013). Indeed, policy makers have recognized that the sectors examined in this study, the banking, ICT, and pharmaceutical industries, are crucial to boosting growth and productivity (Government of Pakistan, 2007; NAVTEC, 2009; PPMA, 2013; World Bank, 2013). High-performance HRM practices could help to do that. This study differs from the dominant literature on HRM in emerging economies in three significant ways. First, it draws on the, to date, most comprehensive survey of a wide range of potential high-performance HR practices in indigenous workplaces in Pakistan, an 
oft overlooked country in the literature (Budhwar and Singh, 2007; Khilji; 2001, 2002). Second, it examines the links between high-performance HR practices and HR-related outcomes amongst indigenous establishments. Existing research on HRM in developing economies often downplays such links (Budhwar and Debrah, 2009; Ramdani et al., 2014). Finally, it sheds light on the applicability and utility of high-performance HR practices in Pakistan, a developing economy and an important site to assess universalistic assumptions about the benefits of certain HR practices (Budhwar and Debrah 2001, 2009).

The following section justifies the selection of HR practices examined in this paper and reviews major studies of those HR measures and the performance outcomes assessed here (absenteeism, quits, and labour productivity). A section that develops the hypotheses and another that specifies the research design and methodology then follow. The subsequent section provides the results. The final section discusses the findings and concludes.

\section{Literature Review}

This paper draws on the universalistic approach to HRM to explore HRM and performance issues in Pakistan. This approach views employees as the firm's key resource, as other sources of competitive advantage are less important than they once were (Pfeffer, 1994: 6). The universalist approach, in contrast to contingency and configurational frameworks, assumes that 'high performance' HR practices will help to improve establishment performance, irrespective of product market, industry, or workforce characteristics (Demirbag et al., 2014; Huselid, 1995: 668; Macky and Boxall, 2007; Marchington and Wilkinson, 2008).

Overall, there is evidence from developed countries to support a link between highperformance HR practices and beneficial workplace outcomes (Combs et al., 2006; Guthrie et al., 2009; Hoque, 1999; Huselid, 1995; Ichniowski et al., 1997; Koch and McGrath, 1996; 
Wood and de Menezes, 2008). However, the majority of the extant research has been conducted on firms or establishments in developed economies, often the US (Tüselmann $e t$ $a l ., 2007)$. Thus, there is a need to deepen our understanding of the links between HRM practices and organizational performance in developing economies (Budhwar and Debrah, 2009), including Pakistan.

Hypothesis Development

In order to capture a broad range of core high-performance HR practices that may help to improve establishment performance, this study draws on Marchington and Wilkinson's (2008) and Pfeffer's (1998) frameworks. In particular, we examine employment security and internal labour markets; selective hiring and sophisticated selection; extensive training, learning, and development; employee involvement, worker voice, and participation; team work; performance-related pay; performance review, appraisal, and career development; the reduction of status differentials; and work-life balance. Whilst there is no consensus on which HR practices are high-performance ones (Guthrie et al., 2009: 112), they often include those selected here (e.g. Collings et al., 2010; Demirbag et al., 2014).

Given the dearth of large-scale studies of HRM in Pakistan, we consider these practices individually rather than collectively, enabling us to provide fine-grained analysis and to examine the influences of culture, religion, and organizational traditions on separate HR practices rather than presuppose the extensive use of particular practices as part of HRM bundles. For instance, Pakistani culture and Islamic values, including collectivism and high power distance, are likely to influence the use and efficacy of the selected practices (Boxall and Purcell, 2011). In addition, precisely because we focus on the largest non-managerial employee group, we will be able to detect any organizational traits, such as centralization and clear status differentials, that some research has found amongst Pakistani firms (e.g. Islam, 
2005; Khilji, 2002) and that are likely to influence HRM practices (Boxall and Purcell, 2011). The examination of the chosen practices is especially salient for the sectors analysed here (banking, ICT, and the pharmaceutical industry), as companies in these sectors have not improved their performance, despite a recognition that they need to do so if economic growth and job quality are to improve (World Bank, 2013). These industries will also rely, to varying degrees, on relatively skilled employees, increasing the potential benefits of highperformance HRM practices (Boxall and Purcell, 2011).

We now review the literature on individual high-performance HRM practices and their associations with performance outcomes; we also evaluate their convergence/divergence with Islamic management philosophy. A critical element in high-performance HRM is employment security. It can influence reciprocity and mutuality at work as well as the psychological contract between employee and employer, leading to enhanced establishment performance (Pfeffer, 1998). Ali (2010) indicates that Islamic work values are founded on the principles of Eshan, or goodness and generosity in interaction and conduct at both a personal and organizational level (see also, Branine and Pollard, 2010). Sedakah, which signifies any sincere or beneficial deed, is associated with Eshan. According to this principle, employers should consider employees as humans above purely economic considerations. This suggests that employers should avoid redundancies as far as possible (Ali, 2010). This can occur either through a formal policy or an informal practice of avoiding lay-offs. However, the principle of Eshan guides rather than proscribes certain actions. Nepotism may also play a role in Pakistani establishments (Islam, 2005), leading to a desire to avoid redundancies whenever possible, but not, necessarily, aiding labour productivity. On the basis of the highperformance HRM literature, we hypothesize that: 
H1: Establishments with policies of no compulsory redundancies will be associated with a) lower absenteeism rates, b) lower quit rates, and c) higher labour productivity. $\mathrm{H} 2$ : Establishments that expect all employees to stay until retirement will be associated with a) lower absenteeism rates, b) lower quit rates, and c) higher labour productivity.

Attracting and selecting high quality staff are central to the high-performance HRM model (Marchington and Wilkinson, 2008). They encourage the selection of employees from a wide pool of applicants (Guest et al., 2003) and the use of employment tests, such as skill and aptitude tests, prior to hiring to check the applicant's suitability (Guthrie et al., 2009), improving establishment performance. The recruitment of employees within an Islamic management system can only take place on the basis of competency, and individuals should not be appointed on the basis of race, colour, age, political power or blood relationships (Ali, 2010: 698; Hashim, 2010). However, collectivism, high power distance and high uncertainty avoidance may result in nepotistic workplace practices (Islam, 2005; Mangi et al., 2012) that differ significantly to high-performance HRM ones and that have a detrimental influence on establishment performance. We, therefore, propose that:

H3: Establishments with recruitment processes that generate as many good/qualified applicants as the establishment needs will be associated with a) lower absenteeism rates, b) lower quit rates, and c) higher labour productivity.

H4: Establishments that conduct one or more employment tests prior to hiring will be associated with a) lower absenteeism rates, b) lower quit rates, and c) higher labour productivity. 
Extensive training, learning and development are crucial high-performance HRM practices (Pfeffer, 1998). Establishments that encourage employees to gain general skills, such as problem-solving and communication skills, as well as ones applicable in a variety of jobs can improve establishment performance (Collings et al., 2010). Islam encourages training and continuous development (Ali, 2010). The Islamic principle of Etqan requires people to struggle for self-improvement in order to do better work (Branine and Pollard, 2010), encouraging workers to learn new skills and be innovative and creative. Once again, the principles underpinning HPWS and Islamic HRM management appear to converge. However, cultural values of high power distance (Mangi et al., 2012) may lead to centralization (Islam, 2004) and an associated reduction in employee training and establishment performance. On this basis, we hypothesize that:

H5: Establishments that provide non-managerial employees with training in a variety of jobs or skills and/or routinely perform more than one job will be associated with a) lower absenteeism rates, b) lower quit rates, and c) higher labour productivity.

H6: Establishments that provide non-managerial employees with intensive/extensive training in generic skills will be associated with a) lower absenteeism rates, b) lower quit rates, and c) higher labour productivity.

Employee involvement and participation are essential components of the high performance paradigm (Marchington and Wilkinson, 2008) and will enhance establishment performance by increasing employee motivation (Birdi et al., 2008). Shura or Consultation is the founding stone of Islamic Administration (Branine and Pollard, 2010), and Islam emphasizes co-operation and consultation in decision making (Abuznaid, 2006), potentially encouraging employee participation in Pakistani establishments (Mellahi and Budhwar, 2010; 
Ramdani et al., 2014). There is also, however, a tradition of paternalistic management and centralized decision making in Pakistani firms, leading to low employee autonomy and initiative (Iqbal, 2008). It should also be noted that trade unions operate under restrictive laws. Only 6.3 per cent of the non-agricultural workforce is unionized (Ghayur, 2009). We have, therefore, focused on direct voice rather than union voice. In line with the highperformance HRM literature, we hypothesize that:

H7: Establishments in which non-managerial employees are involved in programmes designed to elicit participation and employee input (e.g. quality circles, problem solving, or similar groups) will be associated with a) lower absenteeism rates, b) lower quit rates, and c) higher labour productivity.

H8: Establishments that provide non-managerial employees with relevant strategic information will be associated with a) lower absenteeism rates, b) lower quit rates, and c) higher labour productivity.

H9: Establishments that routinely conduct attitude surveys to correct employee morale problems will be associated with a) lower absenteeism rates, b) lower quit rates, and c) higher labour productivity.

As part of high-performance HRM systems, establishments often implement 360degree feedback policies (i.e. feedback from multiple stakeholders) to develop their employees, thereby helping to enhance establishment performance (Guest et al., 2003). The principles behind 360-degree feedback systems comply with Islamic thought: different sources were used to evaluate the performance of individuals in the early days of Islam (Ali, 2010). However, current employee-evaluation practices in many Muslim countries do not comply with these traditions, as they lack credibility and objectivity (Ali, 2010). Moreover, 
Pakistan's cultural traits of high power distance (Mangi et al., 2012) and high uncertainty avoidance (Islam, 2005) may inhibit senior managers' willingness to share authority with workers, limiting the use and efficacy of 360-degree feedback practices. Building on the high-performance HRM literature, we hypothesize that:

H10: Establishments that provide employees with formal feedback from more than one source will be associated with a) lower absenteeism rates, b) lower quit rates, and c) higher labour productivity.

Performance-related pay (PRP) is an integral part of high-performance HR systems (Marchington and Wilkinson, 2008; Pfeffer, 1998), and is, in general, associated with better establishment outcomes (Guthrie et al., 2009). Islam equates hard work to spiritual fulfilment, and emphasizes adequate and reasonable financial rewards (Hashim, 2010). Islamic compensation systems seek to encourage appropriate behaviour; enhance commitment to the organization and wider societal objectives; and steer employees to do their best, while adhering to religious precepts (Ali, 2010). Performance-related pay is, therefore, consistent with Islamic principles. However, cultural characteristics, such as high power distance, may lead to nepotism (Islam, 2004) that, in turn, results in arbitrary and opaque pay schemes. Building on the high-performance HRM literature, we, therefore, hypothesize that:

H11: Establishments that allow non-managerial employees to participate in profit-sharing or share-ownership schemes will be associated with a) lower absenteeism rates, b) lower quit rates, and c) higher labour productivity. 
H12: Establishments that offer additional pay or a pay rise in the past year as a result of individual or collective job performance will be associated with a) lower absenteeism rates, b) lower quit rates, and c) higher labour productivity.

The lack of many status differences between managers and lower-level employees is a pre-condition for the successful implementation of several high-performance HRM practices, such as team working and employee involvement, and encourages all employees to feel valued (Pfeffer, 1998). Such practices are, overall, associated with improved establishment performance (e.g. Wood and de Menezes, 1998). Islam encourages the fair treatment of everyone, irrespective of background or race (Ali, 2010). This implies the equal treatment of all workers, and the removal of many status differences at work. Once again, cultural values in Pakistan may push managers to adopt nepotistic and centralizing HR practices that favour some groups over others (Islam, 2004). We, therefore, propose that:

H13: Establishments with few status differences between managers and the rest of the employees will be associated with a) lower absenteeism rates, b) lower quit rates, and c) higher labour productivity.

To satisfy the demands of their workforce, recruit high-quality employees and avoid problems of absenteeism, several employers have adopted practices to promote work-life balance as part of broader high-performance HRM policies. The existing evidence on the association between work-life balance practices and establishment performance is mixed (Beauregard and Henry, 2009). Islam encourages employees not to work beyond their capacity (Hashim, 2010). Moreover, the Islamic principles of Ehsan and Sedakah imply that employers should consider human aspects while designing their management practices (Ali, 
2010). On the other hand, Pakistani culture often encourages nepotism and centralization (Islam, 2004), which is likely to limit practices to balance work with private lives to favoured groups. We, therefore, hypothesize that:

H14: Establishments that allow employees to take career breaks for child care, elder care and leisure activities will be associated with a) lower absenteeism rates, b) lower quit rates, and c) higher labour productivity.

\section{Research Design and Methodology}

The research investigated high-performance HR practices for non-managerial employees in Pakistani-owned establishments with 20 or more employees. One of the paper's authors collected the data using a structured, face-to-face questionnaire. The respondents were typically establishment general managers. The focus on establishments rather than the corporation as the unit of analysis resolves potential uncertainty surrounding variation in HR policies and outcomes across the company's workplaces (Tüselmann et al., 2007). The reliance on single respondents to report HR practices may lead to non-measurement error (Gerhart, 2007). We checked for common method bias, using Harman's single factor test statistic and confirmatory factor analysis. The data do not suffer from common method bias. The respondents were, in many cases, not HR managers, increasing the validity of the research, as such managers are not predisposed to assess HR practices favourably (Gerhart et al., 2000).

The research was conducted in 2010 in the four main metropolitan cities of Islamabad, Rawalpindi, Lahore and Karachi. The research focuses on three key sectors in Pakistan. They are banking, ICT, and the pharmaceutical industry. Establishments in all three sectors face increased competition, potentially increasing the desirability and efficacy of 
high-performance HRM practices. Much of the industrial activity in Pakistan in the sampled sectors is organized in and around these cities and sectors. Out of a total population of 830 establishments in Pakistan in the sampled sectors, 261 participated in the research (response rate: $31.4 \%$ ). This response rate compares well to related studies that typically have a response rate between 6 and 28 per cent (Becker and Huselid, 1998).

This study focuses on formal work within these three sectors. Employment in the informal economy represents around 73 per cent of all non-agricultural employment in Pakistan, one of the highest figures in the world (World Bank, 2013). The chosen sectors and workplaces do not, therefore, capture the complexity of the Pakistani economy. However, assessing HR practices of whatever description in the informal economy is likely to be difficult for a number of reasons. Most importantly, formal establishments are the more likely than informal ones to adopt 'meaningful' or codified HRM practices (Budhwar and Debrah, 2009). The informal economy is likely to be particularly relevant to the ICT sector, as freelancers play a prominent role in this sector, and ICT free-lancers, either as individuals or as small firms, may not disclose their income in Pakistan for tax and personal-safety reasons (Baloch, 2014). It should, however, be noted that this study focuses on establishments with 20 or more employees. Thus, we do not seek to capture small firms or sole traders.

\section{Dependent Variables}

We asked senior establishment managers to provide their subjective opinions on HR practices and the performance of their workplace in terms of absenteeism, quits, and labour productivity. For absenteeism and labour turnover, respondents were asked to consult their records and/or relevant manager to aid validity and reliability. Labour productivity was captured using a five-point Likert scale adapted from the WERS 2004 survey and was later converted to a dichotomous scale to avoid infringing the minimum sufficiency requirements 
of multivariate analysis (Field, 2009). Table 1 details the operationalization of these outcomes as well as the control variables.

\section{XXX}

Table 1 around here

$\mathrm{XXX}$

We chose these employee-related dependent variables for three main reasons. First, they are more directly related to HR practices than are more 'remote' outcomes, such as profits, that can be influenced by a range of 'non-HRM' factors, including the establishment's institutional setting (Godard, 2004). Second, the HRM literature recognizes that worker-related outcomes are a central issue (Guest, 2011). Finally, even if HR practices do improve establishment profitability, they may not enhance employee well-being (Peccei, 2004), which is likely to be reflected in quits and absenteeism.

\section{Independent Variables}

As noted above, this study draws on Marchington and Wilkinson's (2008) and Pfeffer's (1998) framework to select a wide range of HR practices that are thought to shape establishment performance. Every item used in the current study was drawn from major US and UK studies (e.g. Becker and Huselid, 1998; Guest et al., 2003; Guthrie et al., 2009; Hoque, 1999; Huselid, 1995; Mackay and Boxall, 2007; ), thus increasing the reliability and validity of the research. The HR practices were measured as dichotomous variables.

A standard set of control variables was included in the regressions (Guthrie et al., 2009). In order to dichotomize the 'age', 'size', and 'proportion of the workforce who are non-management employees' variables, relevant arithmetic means were used. 


\section{Data Analysis}

We used logistic regressions to examine the relationship between a single HR practice and the performance of local establishments in Pakistan. Each regression contained all of the control variables (but not the other HR practices). Logistic regressions are sensitive to high intercorrelations among predictor variables. However, running regressions for just one HR practice alongside the control variables eliminated any multicollinearity between the HR practices. Outliers, or those cases with standardized residual values above 3.3 or less than 3.3 (Field, 2009), may affect logistic regressions. We excluded such cases from the analysis. In logistic regressions, the Hosmer-Lemeshow test indicates whether the model is a good fit for the data; the significance of the test statistic should be greater than .05 . Cox and Snell $\mathrm{R}$ squared and Nagelkerke R squared measure the amount of variation in the dependent variable that is explained by the model (Field, 2009).

\section{Results: Prevalence of HR Practices and Establishment Performance}

Table 2 reveals the extent to which HR practices are adopted in the surveyed workplaces. A number of HR practices are common: more than 80 per cent of workplaces have policies to reduce status differences, have good recruitment practices, and provide non-managerial employees with relevant strategic information. The reduction in status differentials and the provision of strategic information indicate that many workplaces in Pakistan adopt an inclusive approach to their workforce. The majority of workplaces have implemented several other HR practices, including implicit job guarantees, training in generic skills, career breaks, and employment tests prior to hiring are commonplace. . Indeed, 44 per cent of workplaces either provide training in a variety of jobs to their non-managerial employees and/or expect these employees to routinely perform more than one job, suggesting that employers do not 
fear losing recently trained staff and that they are creating the necessary conditions for employees to contribute towards organizational development (cf. Khilji, 2002).

\section{XXX}

Table 2 about here

XXX

\section{Establishment Performance}

The results of the regression analysis are shown in Table 3. It shows the associations between individual high-performance practices and the range of performance outcomes after allowing for the influence of the control variables. In Table 3, cells in bold relate to a statistically significant HR practice and have Hosmer-Lemeshow scores that indicate the model fits the data well.

\section{XXX}

Table 3 about here

XXX

\section{Absenteeism}

Interestingly, there are only two HR practices that are statistically significant and that have a Hosmer-Lemeshow score that indicates that the model is appropriate for absenteeism. Those HR measures are 'non-managerial employees receive training in a variety of jobs or skills and/or routinely perform more than one job' and the 'establishment routinely conducts attitude surveys to correct employee morale problems'. Both are associated with lower levels of absenteeism and are statistically significant at the one-per-cent level. These HR policies are a more appropriate means to address absenteeism than practices that focus on eliciting 
views on operational aspects of the establishment through, say, quality circles, as well as profit-sharing schemes that can enhance employee pay (Wood and de Menezes, 2008).

Only one other variable - the 'recruitment process generates as many good/qualified applicants as the establishment needs' - is statistically significant and associated with lower absenteeism; the model that it forms part of does not, however, fit the data well. This finding buttresses the view that the establishment is seen as an attractive place to work: people wish to work in the establishment and, once there, are less likely to be absent without good reason.

\section{Quit Rates}

The same two variables that are statistically significant and, when in combination with the control variables in a broader model, provide a good fit for the data for absenteeism also do so for quits. Both are associated with lower quit rates and are statistically significant at the one-per-cent level. Two more HR practices also meet those criteria and are linked to belowaverage employee-turnover rates. They are the 'recruitment process generates as many good/qualified applicants as the establishment needs' and 'one or more employment test is conducted prior to hiring'. The importance, once again, of the 'non-managerial employees receive training in a variety of jobs or skills and/or routinely perform more than one job' and the 'establishment routinely conducts attitude surveys to correct employee morale problems' variables underlines the robustness of the research: high levels of absenteeism and quits are likely to be influenced by similar factors (Allen and Tüselmann, 2009).

The other two variables that are statistically significantly associated with lower quits and are part of models that fit the data well (recruitment processes that generate sufficient numbers of appropriately skilled applicants and the use of employment tests prior to appointment) suggest that those establishments that meet these criteria are attractive places to work. Such workplaces are able to attract and retain employees who have the required skills 
and who are well suited to the job and workplace. Establishments that are seen as less attractive places to work are unlikely to generate as many applications from suitably qualified individuals and may not be in a position to carry out employment tests to ensure compatibility (Combs et al., 2006; cf. Wood and de Menezes, 1998).

Establishments that have a 'formal policy of no compulsory redundancy' are not more likely to be associated with lower quit rates than those workplaces without such a policy, indicating that employees do not remain at an establishment as a result of this measure (cf. Guest et al., 2003; Wood and de Menezes, 2008). Other aspects of job security, such as the expectation that all employees will stay until retirement, are important elements of previous studies and can indicate the presence of internal labour markets (Hoque, 1999; Mackay and Boxall, 2007). Whilst this variable here is statistically significant and associated with lower quit rates, the broader model, of which it forms a part, is not a good fit for the data. These mixed findings tentatively indicate that such expectations encourage employees to stay with the establishment. Importantly, increased tenure can aid productivity, as will be shown below.

Other variables that are statistically significant, but that are part of models that do not fit the data well are: non-managerial employees 'receive intensive/extensive training in generic skills', 'are involved in programmes designed to elicit participation and employee input', 'are provided with relevant strategic information', 'receive formal feedback from more than one source (i.e. feedback from several individuals such as supervisors, peers etc.)', and 'participate in profit sharing or share ownership schemes'. They are all associated with lower quit rates. With the exception of the 'quality circle' variable, which is significant at the five-per-cent level, all of these practices are statistically significant at the one-per-cent level. Such policies may help to lower quit rates, but that association is weak when looked at as part of a broader model. The other HR practices are not statistically significant. 


\section{Labour productivity}

Once again, the 'non-managerial employees receive training in a variety of jobs or skills and/ or routinely perform more than one job' and the 'establishment routinely conducts attitude surveys to correct employee morale problems' variables are statistically significant and part of models that provide a good fit for the labour-productivity data. Both are associated with higher levels of labour productivity and are statistically significant at the one-per-cent level. This supports the robustness of the research: establishments with lower levels of absenteeism and quits can be expected to have more productive staff. Training in itself can help to improve productivity and being skilled in more than one job can facilitate the provision of productivity-enhancing suggestions from employees (Ichniowski et al., 1997; Hoque, 1999; Guthrie et al., 2009). Providing workers with a voice can help to heighten efficiency (Godard, 2004).

Several other HR practices meet the criteria of being statistically significant and being part of models that provide a good fit for the data. They are 'the organization has a formal policy of no compulsory redundancy', 'the establishment expects all employees to stay till retirement', 'one or more employment test is conducted prior to hiring', 'non-managerial employees receive intensive/extensive training in generic skills', 'non-managerial employees are provided with relevant strategic information', and 'there are few status differences in the establishment'. Having employees who remain with the workplace can aid labour productivity, especially if the skills that employees have are largely tacit (Allen, 2014; Koch and McGrath, 1996). Similarly, training in specific and generic skills may enhance employees' understanding of the tasks involved within the company and how their work relates to other activities, potentially helping to improve productivity (Combs et al., 2006; Guthrie et al., 2009; Ichniowski et al., 1997; Wood and de Menezes, 2008). Systematic 
selection and recruitment can also be expected to increase the likelihood that new recruits meet the job requirements (Combs et al., 2006; Huselid, 1995; Koch and McGrath, 1996).

Most of these variables are statistically significant at the one-per-cent level. Two 'the establishment has a formal policy of no compulsory redundancy' and 'non-managerial employees are provided with relevant strategic information' - are statistically significant at the ten-per-cent level. The former indicates that it is more important for the workplace to have the expectation that 'all employees will stay until retirement', which is statistically significant at the one-per-cent level, rather than having a formal 'no compulsory redundancy' policy. The result for the 'strategic information' variable tentatively suggests that increased establishment transparency and employees having an enhanced understanding of their roles can facilitate productivity increases. However, training and providing employees with a voice to express their opinions are more likely to be associated with higher productivity, as they are statistically significant at the one-per-cent level.

There are four HR practices that, individually, are statistically significant, but that are not part of models that provide a good fit for the data. They are non-managerial employees 'are involved in programmes designed to elicit participation and employee input', 'receive formal feedback from more than one source', 'participate in profit-sharing or shareownership schemes', 'the establishment allows career breaks to employees for child care, elder care and leisure activities'. With the exception of the 'profit-sharing' practice, which is statistically significant at the five-per-cent level, all are significant at the one-per-cent level. The findings for the 'receive formal feedback' practice reflects the mixed results found in previous studies (Guest et al., 2003; Guthrie et al., 2009; Huselid, 1995; cf. Combs et al., 2006; Wood and de Menezes, 2008).

\section{Discussion and Conclusion}


This study has drawn on the, to date, most comprehensive survey of high-performance HR practices and outcomes in Pakistani workplaces. Several high-performance HR practices are common amongst the surveyed establishments: more than 80 per cent of workplaces have policies to reduce status differences, have good recruitment practices, and provide nonmanagerial employees with relevant strategic information. More than half of those workplaces analysed had implemented several other HR practices. Implicit job guarantees, training in generic skills, career breaks, and employment tests prior to hiring are commonplace. This evidence suggests that, in general, Pakistani establishments in the three sectors examined here have adopted HRM practices that conform to models based on highperformance HRM paradigms and Islamic principles, such as Ehsan and Sedakah that emphasize equal treatment and a consideration of human aspects while designing work practices.

The other practices examined here are less frequently adopted, although all of the individual practices were adopted by least one third of all establishments. So, for instance, around four out of every ten surveyed establishments have performance-related pay, seek the opinions of their employees to improve morale, and implement 360-degree feedback policies, indicating the potential for cultural traits, such as high power distance, to influence the prevalence of important high-performance HRM practices.

The anticipated benefits, from a universalistic perspective, are not always present for most high-performance practices. The research did confirm two of the hypotheses: H5 and $\mathrm{H} 9$ on the provision of training to non-managerial employees so that they can carry out a variety of jobs and the regular use of surveys to improve employee morale) are consistently associated with better outcomes on all three measured examined here (absenteeism, quits, and labour productivity). Approximately a half of the other hypotheses received some support: 
the association between the HR practice and at least one of the outcomes, most frequently labour productivity, was statistically significant and the model that the practice formed part of provided a good fit for the data. Overall, then, the findings provide limited support for the view that high-performance HRM practices are associated with better establishment outcomes in Pakistan. Such practices and outcomes also conform to Islamic views of HRM, but contradict those that prioritize cultural factors.

However, cultural values cannot be discounted entirely. As the analyzed models often do not fit the data well, cultural traits may affect the implementation of HRM practices. For instance, high power distance may not prevent the use of profit-sharing schemes in Pakistani establishments. Such schemes appear to have the desired effect, as they are statistically significantly associated with lower quits and higher labour productivity. Cultural traits may, though, inhibit managers' willingness to see lower-level employees gain substantially from such schemes, thus, reducing the overall impact of them and helping to explain why the overall model that includes profit sharing and the control variables does not fit the data well. Similarly, nepotism may influence how establishments implement performance-related pay, resulting in statistically non-significant links between that practice and the outcomes examined here. Future research, not just that on Pakistani establishments but studies of workplaces in countries with Muslim majorities, could, therefore, seek to examine how cultural traits influence the implementation of particular HRM practices and, hence, shape establishment performance. In a broad sense, high-performance HRM practices may look similar in many countries, but their peculiarities may vary greatly and have important implications for any associated benefits.

Our questionnaire relied solely on the responses and views of managers to examine the links between HRM and performance. This, potentially, introduces a unitaristic bias into 
our results, leading to too great an emphasis on 'good' HRM practices, such as the reduction in status differentials and the provision of strategic information to employees, and their benefits. Lower-level employees may have a very different view of HRM and associated outcomes within their establishment (Guest, 2011). Future research could, therefore, analyse the perspective of lower-level employees to deepen yet further our knowledge of HRM and establishment outcomes. Importantly, future studies could assess how the HRM practices examined here influence work intensification, work-life balance, and workplace stress amongst different groups of employees in Pakistan, a country characterized by high power distance and high uncertainty avoidance that may influence how HRM polices are actually implemented and experienced (for a related study, see Mackay and Boxall, 2008).

Future research could also examine the reasons why certain establishments in Pakistan adopt these high-performance HR practices and benefit from them, whilst others do not. Studies could, for instance, examine the specific industry contexts, firm strategies, and institutional settings of workplaces (Allen, 2014). In general, establishments in sectors that are marked by competition on quality rather than price are likely to pursue strategies that are contingent upon highly skilled employees who are difficult to replace; they can be expected to adopt HR practices that encourage their participation and enhance their satisfaction (Allen, 2014). Amongst firms in the same industry, but different market segments, company and HRM strategies will vary (Boxall, 2003); within a particular establishment, HR practices can differ for various employee groups, depending on their value to the firm and the uniqueness of their skills (Guest, 2011). Incorporating firm and HRM strategies as well as industry contexts and a range of firm variables, such as life-cycle stage, into the analysis would provide a deeper understanding of the HRM practices associated with different employee groups (core and periphery workers) in Pakistani establishments within and across different industries. Similarly, institutions shape HR practices and outcomes (Allen, 2014; Demirbag et 
$a l ., 2014)$. The prevalence of family-owned firms characterizes some institutional environments, including Pakistan's, potentially facilitating longer-term strategies amongst companies and higher investments in employees' firm-specific skills (Breton-Miller and Miller, 2006).

Despite these limitations, this research has helped to fill an important gap in the literature by providing much information on both the extent of particular HR practices in Pakistan and their associations with workplace-related outcomes. Pakistan is often overlooked in studies of HRM in emerging economies. Yet workplaces in Pakistan, as this research has shown, can gain from the use of certain high-performance HR practices. This is not just a concern for owners and managers within those establishments, but for employees, too. The latter group's working conditions may be better in workplaces with higher performance levels. In addition, by encouraging workplaces to adopt certain HR practices, the Government of Pakistan may be able to help the country achieve its overall economic objectives.

\section{References}

Abuznaid, S. (2006), 'Islam and management: what can be learned?', Thunderbird International Business Review, Vol. 48 No. 1, pp. 125-139.

Ali, A.J. (2010), 'Islamic challenges to HR in modern organizations', Personnel Review, Vol. 39 No. 6, pp. 692-711.

Allen, M.M.C. (2014), 'Business systems theory and employment relations', in A. Wilkinson, G.T. Wood and R. Deeg (eds), The Oxford Handbook of Employment Relations: Comparative Employment Systems, Oxford, Oxford University Press, pp. 86-113. 
Allen, M.M.C. and Tüselmann, H.-J. (2009), 'All powerful Voice? The need to include "Exit", "Loyalty" and "Neglect" in empirical studies too', Employee Relations, Vol. 31 No. 5, pp. 538-552.

Baloch, F. (2014), Upward move: Pakistan's ICT sector to cross \$10b mark, says P@SHA', The Express Tribune, July 20, 2014 http://tribune.com.pk/story/738036/upward-movepakistans-ict-sector-to-cross-10b-mark-says-psha/.

Beauregard, T.A. and Henry, L.C. (2009), 'Making the link between work-life balance practices and organizational performance', Human Resource Management Review, Vol. 19 No. 1, pp. 9-22.

Becker, B.E. and Huselid, M.A. (1998), 'High performance work systems and firm performance: a synthesis of research and managerial implications', Research in Personnel and Human Resource Management, Vol. 16, pp. 53-101.

Birdi, K., Clegg, C., Patterson, M., Robinson, A., Stride, C., Wall, T., and Wood, S. (2008), 'The impact of human resource and operational management practices on company productivity: a longitudinal study', Personnel Psychology, Vol. 61 No. 3, pp. 467-501.

Boxall, P. (2003), 'HR strategy and competitive advantage in the service sector', Human Resource Management Journal, Vol. 13 No. 3, pp. 5-20.

Boxall, P. and Purcell, J. (2011), Strategy and Human Resource Management, 3rd edition. Basingstoke: Palgrave Macmillan.

Branine, M., and Pollard, D. (2010), 'Human resource management with Islamic management principles', Personnel Review, Vol. 39 No.6, pp 712-727.

Breton-Miller, I. and Miller, D. (2006), 'Why do some family businesses out-compete? Governance, long-term orientations, and sustainable capability', Entrepreneurship Theory and Practice, Vol. 30 No. 6, pp. 731-746. 
Budhwar, P., and Debrah, Y. (eds) (2001), Human Resource Management in Developing Countries, London, Routledge.

Budhwar, P.S. and Debrah, Y.A. (2009), 'Human resource management in developing countries', in A. Wilkinson, N. Bacon, T. Redman and S. Snell (eds), The Sage Handbook of Human Resource Management, London, Sage, pp. 393-406.

Budhwar, P.S. and Mellahi, K. (eds) (2006), Managing Human Resources in the Middle East, London: Routledge.

Budhwar, P. and Mellahi, K. (2007), 'Introduction: human resource management in the Middle East', International Journal of Human Resource Management, Vol. 18 No. 1, pp. 2-10.

Budhwar, P. and Singh, V. (2007), 'The Indian subcontinent context', Employee Relations, Vol. 29 No. 6, pp. n.a.

Chand, M. and Katou, A.A. (2007), 'The impact of HRM practices on organisational performance in the Indian hotel industry', Employee Relations, Vol. 29 No. 6, pp. 576594.

Chandrakumara, A. (2007), 'Does HRM fit really matter to citizenship and task performance? Sri Lankan manufacturing sector sxperience, Employee Relations, Vol. 29 No. 6, pp. 611-639.

Chaudhry, S. (2013), 'Managerial career development in a developing host-country context: a study of American multinationals in Pakistan', International Journal of Human Resource Management, Vol. 24 No. 3, pp. 558-578.

Collings, D., Demirbag, M., Mellahi, K., and Tatoglu, E. (2010), 'Strategic orientation, human resource management practices and organizational outcomes: evidence from Turkey,' International Journal of Human Resource Management, Vol. 21 No. 14, pp. 2589-2631. 
Combs, J., Liu, Y., Hall, A., and Ketchen, D. (2006), 'How much do high performance work practices matter? A meta-analysis of their effects on organizational performance', Personnel Psychology, Vol. 59 No. 3, pp. 501-528.

Debrah, Y.A. and Budhwar, P.S. (2001), 'Conclusion: international competitive pressures and the challenges for HRM in developing countries', in P.S. Budhwar and Y.A. Debrah (eds), Human Resource Management in Developing Countries, London, Routledge, pp. 238-254.Demirbag, M., Collings, D.G., Tatoglu, E., Mellahi, K. and Wood, G. (2014), 'High-performance work systems and organizational performance in emerging economies: evidence from MNEs in Turkey', Management International Review, Vol. 54 No. 3, pp. 325-359.

Field, A. (2009), Discovering Statistics using SPSS, Third Edition, Sage Publications Limited, London.

Gerhart, B. (2007), 'Modelling HRM and performance linkages', in P. Boxall, J. Purcell, and P. Wright (eds) The Oxford Handbook of Human Resource Management, Oxford, Oxford University Press, pp. 552-580. Gerhart, B., Wright, P.M., McMahan, G.C., and Snell, S.A. (2000), 'Measurement error in research on human resource and firm performance: how much error is there and how does it influence effect size estimates?', Personnel Psychology, Vol. 53 No. 4, pp. 803-834.

Ghayur, S. (2009), Evolution of the Industrial Relations System in Pakistan. New Delhi, India, ILO Office for South Asia.

Godard, J. (2004), 'A critical assessment of the high-performance paradigm', British Journal of Industrial Relations, Vol. 42 No. 2, pp. 350-382.

Government of Pakistan (2007), Vision 2030: Pakistan in the 21st Century. Islamabad, Planning Commission. 
Guest, D.E. (2011), 'Human resource management and performance: still searching for some answers', Human Resource Management Journal, Vol 21 No. 1, pp. 3-13

Guest, D.E., Michie, J., Conway, N., and Sheehan, M. (2003), 'Human resource management and corporate performance in the UK', British Journal of Industrial Relations, Vol. 41 No. 2, pp. 291-314.

Guthrie, J.P., Flood, P.C., Liu, W. and MacCurtain, S. (2009), 'High performance work systems in Ireland: human resource and organizational outcomes', International Journal of Human resource Management, Vol. 20 No. 1, pp. 112-125.

Hashim, J., (2010), 'Human resource management practices on organisational commitment', Personnel Review, Vol. 39 No. 6, pp.785-799.

Hoque, K. (1999), 'Human resource management and performance in the UK hotel industry', British Journal of Industrial Relations, Vol. 37 No. 3, pp. 419-443.

Huselid, M.A. (1995), 'The impact of human resource management practices on turnover, productivity, and corporate financial performance', Academy of Management Journal, Vol. 38 No. 3, pp. 635-672.

Ichniowski, C., Shaw, K., and Prennushi, G. (1997), 'The effects of human resource management practices on productivity', American Economic Review, Vol. 87 No. 3, pp. 291-313.Iqbal, A. (2008), 'Assessing the managerial styles in Pakistani context', in K. Grant (ed.), 4th European Conference on Management, Leadership and Governance, Reading, UK: Academic Publishing Limited.

Islam N. (2005), 'Sifarish, sycophants, power and collectivism: administrative culture in Pakistan', International Review of Administrative Sciences, Vol. 70 No. 2, pp. 311-330.

Khilji, S.E. (2001), Human resource management in Pakistan', in P.S. Budhwar and Y.A. Debrah (eds), Human Resource Management in Developing Countries, London, Routledge, pp. 102-120. 
Khilji, S.E. (2002), 'Modes of convergence and divergence: an integrative view of multinational practices in Pakistan', International Journal of Human Resource Management, Vol. 13 No. 2, pp. 232-253.

Koch, M.J., and McGrath, R.G. (1996), 'Improving labor productivity: human resource management policies do matter', Strategic Management Journal, Vol. 17 No. 5, pp. $335-354$.

Macky, K., and Boxall, P. (2007), 'The relationship between "high performance work practices" and employee attitudes: an investigation of additive and interaction effects', International Journal of Human Resource Management, Vol. 18 No. 4, pp. 537-567.

Macky, K., and Boxall, P. (2008), 'High-involvement work processes, work intensification and employee well-being: a study of New Zealand worker experiences', Asia Pacific Journal of Human Resources, Vol. 46 No. 1, pp. 38-55.

Mangi, R.A., Jhatial, A.A., Shah, S.A.A. and Ghumro, I.A. (2012), 'Human resource management practices in private sector organisations in Pakistan: study of cultural influences', Global Journal of Management and Business Research, Vol. 12 No. 7, pp. 20-30.

Marchington, M., and Wilkinson, A. (2008), Human Resource Management at Work, $4^{\text {th }}$ edition, London, CIPD.

Mellahi, K. and Budhwar, P.S. (2010), 'Introduction: Islam and human resource management', Personnel Review, Vol. 39 No. 6, pp. 685-691.

NAVTEC (National Vocational and Technical Education Commission) (2009), The National Skills Strategy 2009-2013, Islamabad, NAVTEC.

Peccei, R. (2004), Human Resource Management and the Search for the Happy Workplace, Rotterdam, Inaugural Lecture Erasmus University Institute of Management. 
Pfeffer, J. (1998), The Human Equation: Building Profits by Putting People First, Boston, MA, Harvard Business School Press.

PPMA (Pakistan Pharmaceutical Manufacturers’ Association) (2013), Pakistan Pharmaceutical Industry, available at: http://www.ppma.org.pk/PPMAIndustry.aspx; accessed 15 January 2013.

Raman, S.R., Budhwar, P. and Balasubramanian, G. (2007), 'People management issues in Indian KPOs', Employee Relations, Vol. 29 No. 6, pp. 696-710.

Ramdani, B., Mellahi, K.,Guermat, C. and Kechad, R. (2014), 'The efficacy of high performance work practices in the Middle East: evidence from Algerian firms', International Journal of Human Resource Management, Vol. 25 No. 2, pp. 252-275.

Tayeb, M. (1997), 'Islamic revival in Asia and human resource management', Employee Relations, Vol. 19 No. 4, pp. 352-64.

Tüselmann, H.-J., McDonald, F., Heise, A., Allen, M.M.C., and Voronkova, S. (2007), Employee Relations in Foreign-Owned Subsidiaries: German Multinational Companies in the UK, Basingstoke, Palgrave Macmillan.

Wood, S. (1999), 'Getting measure of the transformed high performance organization', British Journal of Industrial Relations, Vol. 37 No. 3, pp. 391-417.

Wood, S. and de Menezes, L. (1998), 'High commitment management in the UK: evidence from the Workplace Industrial Relations Survey, and Employers: Manpower and Skills Practices Survey', Human Relations, Vol. 51 No. 4, pp. 485-515.

Wood, S. and de Menezes, L.M. (2008), 'Comparing perspectives on high involvement management and organizational performance across the British economy', International Journal of Human Resource Management, Vol. 19 No. 4, pp. 639-682.

World Bank (2013), Pakistan: Finding the Path to Job-Enhancing Growth, Islamabad, World Bank. 
Yasmin, R. (2008), 'A study on the effects of strategic HRM systems on performance: the case of Pakistani manufacturing companies', Japanese Journal of Administrative Science, Vol. 21 No. 1, pp. 47-60. 
Table 1 Operationalization of Dependent and Control Variables

\begin{tabular}{|c|c|c|}
\hline Measure & Question & Operationalization \\
\hline \multicolumn{3}{|c|}{ Dependent Variables } \\
\hline Absenteeism & $\begin{array}{l}\text { Over the last } 12 \text { months approximately what } \\
\text { percentage of working days was lost through } \\
\text { employee sickness or absence without permission? } \\
\text { Adapted from WERS } 2004\end{array}$ & $\begin{array}{l}\text { Establishments } \\
\text { with above- } \\
\text { average } \\
\text { absenteeism rates } \\
=1 \text {; below } \\
\text { average }=0\end{array}$ \\
\hline Quit rate & $\begin{array}{l}\text { During the last } 12 \text { months approximately what } \\
\text { percentage of non-managerial employees in this } \\
\text { establishment left or resigned voluntarily? } \\
\text { Adapted from WERS } 2004 \text { and Tüselmann } \text { et al. } \\
\text { (2007). }\end{array}$ & $\begin{array}{l}\text { Establishments } \\
\text { with above- } \\
\text { average quit rates } \\
=1 ; \text { below } \\
\text { average }=0\end{array}$ \\
\hline $\begin{array}{l}\text { Labour } \\
\text { productivity }\end{array}$ & $\begin{array}{l}\text { How would you assess your establishment's current } \\
\text { labour productivity compared with other } \\
\text { establishments in the same industry? } \\
\text { Adapted from WERS } 2004 \text { and Tüselmann et al. } \\
\text { (2007). }\end{array}$ & $\begin{array}{l}\text { Establishments } \\
\text { with above- } \\
\text { average } \\
\text { productivity }=1 \text {; } \\
\text { average or below } \\
\text { average } 0\end{array}$ \\
\hline \multicolumn{3}{|l|}{ Control Variables } \\
\hline Industry & $\begin{array}{l}\text { What is the main nature of the business at this } \\
\text { establishment? }\end{array}$ & $\begin{array}{l}0= \\
\text { manufacturing; } 1 \\
=\text { services }\end{array}$ \\
\hline Age & $\begin{array}{l}\text { How long has your establishment been working in } \\
\text { Pakistan? }\end{array}$ & $\begin{array}{l}0=10 \text { years or } \\
\text { fewer; } 1=11 \text { or } \\
\text { more years }\end{array}$ \\
\hline Size & $\begin{array}{l}\text { What is the number of employees at this } \\
\text { establishment? }\end{array}$ & $\begin{array}{l}0=93 \text { or fewer; } \\
1=94 \text { or more }\end{array}$ \\
\hline $\begin{array}{l}\text { Non-managerial } \\
\text { employees }\end{array}$ & $\begin{array}{l}\text { What proportion of your workforce is made up of } \\
\text { non-managerial employees? }\end{array}$ & $\begin{array}{l}0=\text { less than } 83 \\
\text { per cent; } 1=\text { more } \\
\text { than } 83.01 \text { per } \\
\text { cent }\end{array}$ \\
\hline
\end{tabular}


Table 2 Descriptive Statistics

\begin{tabular}{|l|r|}
\hline HR Practice & Per cent Yes/Agree \\
\hline The organization has a formal policy of no compulsory redundancy & \\
\hline The establishment expects all employees to stay till retirement & $33 \%$ \\
\hline Recruitment process generates as many good/qualified applicants as the establishment needs & $72 \%$ \\
\hline One or more employment tests are conducted prior to hiring & $88 \%$ \\
\hline Non-managerial employees receive training in a variety of jobs or skills and/or routinely perform more than one job & $54 \%$ \\
\hline Non-managerial employees receive intensive/extensive training in generic skills & $44 \%$ \\
\hline $\begin{array}{l}\text { Non-managerial employees are involved in programmes designed to elicit participation and employee input (e.g. } \\
\text { quality circles, problem solving, similar groups) }\end{array}$ & $62 \%$ \\
\hline Non-managerial employees are provided with relevant strategic information & $46 \%$ \\
\hline Workplace routinely conducts attitude surveys to correct employee morale problems & $90 \%$ \\
\hline $\begin{array}{l}\text { Employees receive formal feedback from more than one source (i.e. feedback from several individuals such as } \\
\text { supervisors, peers etc.) }\end{array}$ & $38 \%$ \\
\hline Non-managerial employees participate in profit-sharing or share-ownership schemes & $40 \%$ \\
\hline Offered additional pay or offered pay rise in past year as result of job performance or work in a team & $39 \%$ \\
\hline There are few status differences in the establishment between managers and the rest of the employees & $37 \%$ \\
\hline The establishment allows career breaks to employees for child care, elder care and leisure activities & $82 \%$ \\
\hline
\end{tabular}

Note: $\mathrm{N}=261$. 
$\underline{\text { Table } 3 \text { HR Practices and Establishment Outcomes }}$

\begin{tabular}{|c|c|c|c|c|c|c|c|c|c|c|c|c|c|c|c|}
\hline & \multicolumn{5}{|c|}{ Absenteeism } & \multicolumn{5}{|c|}{ Quits } & \multicolumn{5}{|c|}{ Labour Productivity } \\
\hline HR Practice & B Values & $\begin{array}{l}\text { Odds } \\
\text { ratio }\end{array}$ & H-L & $\begin{array}{c}\mathrm{C} \& \mathrm{~S} \\
\mathrm{R}^{2}\end{array}$ & $\begin{array}{c}\text { Nagel } \\
\mathrm{R}^{2}\end{array}$ & B Values & $\begin{array}{c}\text { Odds } \\
\text { ratio }\end{array}$ & H-L & $\begin{array}{c}\mathrm{C} \& \mathrm{~S} \\
\mathrm{R}^{2}\end{array}$ & $\begin{array}{c}\text { Nagel } \\
\mathrm{R}^{2}\end{array}$ & B Values & $\begin{array}{c}\text { Odds } \\
\text { ratio }\end{array}$ & H-L & $\begin{array}{c}\mathrm{C} \& \mathrm{~S} \\
\mathrm{R}^{2}\end{array}$ & $\begin{array}{c}\text { Nagel } \\
\mathrm{R}^{2}\end{array}$ \\
\hline $\begin{array}{l}\text { The organization has a } \\
\text { formal policy of no } \\
\text { compulsory } \\
\text { redundancy }\end{array}$ & -.342 & .710 & .001 & .096 & .131 & .243 & 1.275 & .060 & .160 & .213 & $-.571 *$ & .565 & .068 & .218 & .291 \\
\hline $\begin{array}{l}\text { The establishment } \\
\text { expects all employees } \\
\text { to stay till retirement }\end{array}$ & -.407 & .665 & .027 & .097 & .133 & $-2.435 * * *$ & .088 & .008 & .301 & .402 & $1.274 * * *$ & 3.54 & .052 & .256 & .342 \\
\hline $\begin{array}{l}\text { Recruitment process } \\
\text { generates as many } \\
\text { good/qualified } \\
\text { applicants as the } \\
\text { establishment needs }\end{array}$ & $-1.179 * * *$ & .307 & .012 & .123 & .169 & $-1.455 * * *$ & .233 & .439 & .232 & .310 & .729 & 2.073 & .026 & .223 & .297 \\
\hline $\begin{array}{l}\text { One or more } \\
\text { employment tests are } \\
\text { conducted prior to } \\
\text { hiring }\end{array}$ & -.110 & .896 & .000 & .091 & .125 & $-1.041 * * *$ & .353 & .471 & .224 & .300 & $1.064 * * *$ & 2.898 & .089 & .243 & .324 \\
\hline $\begin{array}{l}\text { Non-managerial } \\
\text { employees receive } \\
\text { training in a variety } \\
\text { of jobs or skills and/ } \\
\text { or routinely perform } \\
\text { more than one job }\end{array}$ & $-.777 * * *$ & .460 & .205 & .117 & .160 & $-.1 .631 * * *$ & .196 & .260 & .253 & .338 & $.930 * * *$ & 2.534 & .074 & .239 & .318 \\
\hline $\begin{array}{l}\text { Non-managerial } \\
\text { employees receive } \\
\text { intensive/extensive } \\
\text { training in generic } \\
\text { skills }\end{array}$ & -.386 & .679 & .037 & .098 & .134 & $-1.906 * * *$ & .149 & .008 & .298 & .397 & $1.219 * * *$ & 3.385 & .567 & .256 & .342 \\
\hline
\end{tabular}




\begin{tabular}{|c|c|c|c|c|c|c|c|c|c|c|c|c|c|c|c|}
\hline & \multicolumn{5}{|c|}{ Absenteeism } & \multicolumn{5}{|c|}{ Quits } & \multicolumn{5}{|c|}{ Labour Productivity } \\
\hline HR Practice & B Values & $\begin{array}{l}\text { Odds } \\
\text { ratio }\end{array}$ & $\mathrm{H}-\mathrm{L}$ & $\begin{array}{c}\mathrm{C} \& \mathrm{~S} \\
\mathrm{R}^{2}\end{array}$ & $\begin{array}{c}\text { Nagel } \\
\mathrm{R}^{2}\end{array}$ & B Values & $\begin{array}{l}\text { Odds } \\
\text { ratio }\end{array}$ & $\mathrm{H}-\mathrm{L}$ & $\begin{array}{c}\mathrm{C} \& S \\
\mathrm{R}^{2}\end{array}$ & $\begin{array}{c}\text { Nagel } \\
\mathrm{R}^{2}\end{array}$ & B Values & $\begin{array}{l}\text { Odds } \\
\text { ratio }\end{array}$ & $\mathrm{H}-\mathrm{L}$ & $\begin{array}{c}\mathrm{C} \& S \\
\mathrm{R}^{2}\end{array}$ & $\begin{array}{c}\text { Nagel } \\
\mathrm{R}^{2}\end{array}$ \\
\hline $\begin{array}{l}\text { Non-managerial } \\
\text { employees are } \\
\text { involved in } \\
\text { programmes designed } \\
\text { to elicit participation } \\
\text { and employee input } \\
\text { (e.g. quality circles, } \\
\text { problem solving, } \\
\text { similar groups) }\end{array}$ & .009 & 1.009 & .004 & .091 & .124 & $-1.041 * *$ & .535 & .006 & .189 & .252 & $.788 * * *$ & 2.198 & .000 & .234 & .312 \\
\hline $\begin{array}{l}\text { Non-managerial } \\
\text { employees are } \\
\text { provided with relevant } \\
\text { strategic information }\end{array}$ & -.336 & .714 & .014 & .085 & .116 & $-1.548 * * *$ & .213 & .023 & .176 & .235 & $1.027 *$ & 2.792 & .175 & .224 & .298 \\
\hline $\begin{array}{l}\text { Workplace routinely } \\
\text { conducts attitude } \\
\text { surveys to correct } \\
\text { employee morale } \\
\text { problems }\end{array}$ & $-1.128 * * *$ & .324 & .064 & .143 & .197 & $-2.325 * * *$ & .098 & .110 & .326 & .436 & $1.267 * * *$ & 3.551 & .094 & .259 & .346 \\
\hline $\begin{array}{l}\text { Employees receive } \\
\text { formal feedback from } \\
\text { more than one source } \\
\text { (i.e. feedback from } \\
\text { several individuals } \\
\text { such as supervisors, } \\
\text { peers etc. }\end{array}$ & -.354 & .702 & .026 & .097 & .133 & $-1.055 * * *$ & .348 & .002 & .199 & .266 & $1.134 * * *$ & 3.108 & .011 & .341 & .455 \\
\hline
\end{tabular}




\begin{tabular}{|c|c|c|c|c|c|c|c|c|c|c|c|c|c|c|c|}
\hline & \multicolumn{5}{|c|}{ Absenteeism } & \multicolumn{5}{|c|}{ Quits } & \multicolumn{5}{|c|}{ Labour Productivity } \\
\hline HR Practice & B Values & $\begin{array}{l}\text { Odds } \\
\text { ratio }\end{array}$ & $\mathrm{H}-\mathrm{L}$ & $\begin{array}{c}\mathrm{C} \& S \\
\mathrm{R}^{2}\end{array}$ & $\begin{array}{c}\text { Nagel } \\
\mathrm{R}^{2}\end{array}$ & B Values & $\begin{array}{l}\text { Odds } \\
\text { ratio }\end{array}$ & $\mathrm{H}-\mathrm{L}$ & $\begin{array}{c}\mathrm{C} \& S \\
\mathrm{R}^{2}\end{array}$ & $\begin{array}{c}\text { Nagel } \\
\mathrm{R}^{2}\end{array}$ & B Values & $\begin{array}{l}\text { Odds } \\
\text { ratio }\end{array}$ & $\mathrm{H}-\mathrm{L}$ & $\begin{array}{c}\mathrm{C} \& S \\
\mathrm{R}^{2}\end{array}$ & $\begin{array}{c}\text { Nagel } \\
\mathrm{R}^{2}\end{array}$ \\
\hline $\begin{array}{l}\text { Non-managerial } \\
\text { employees participate } \\
\text { in profit sharing or } \\
\text { share ownership } \\
\text { schemes }\end{array}$ & -.155 & .594 & .036 & .085 & .116 & $-1.455 * * *$ & .233 & .010 & .246 & .328 & $.621 * *$ & 1.861 & .008 & .210 & .281 \\
\hline $\begin{array}{l}\text { Offered additional pay } \\
\text { or offered pay rise in } \\
\text { past year as result of } \\
\text { job performance or } \\
\text { work in a team }\end{array}$ & .112 & 1.118 & .001 & .092 & .126 & -.316 & .729 & .041 & .181 & .241 & .417 & 1.517 & .009 & .214 & .286 \\
\hline $\begin{array}{l}\text { There are few status } \\
\text { differences in the } \\
\text { establishment between } \\
\text { managers and the rest } \\
\text { of the employees }\end{array}$ & .709 & 2.031 & .036 & .095 & .130 & -.375 & .687 & .005 & .151 & .201 & $1.062 * * *$ & 2.893 & .063 & .221 & .294 \\
\hline $\begin{array}{l}\text { The establishment } \\
\text { allows career breaks } \\
\text { to employees for child } \\
\text { care, elder care and } \\
\text { leisure activities }\end{array}$ & .296 & 1.345 & .004 & .095 & .131 & -.180 & .835 & .012 & .159 & .212 & $.887 * * *$ & 2.427 & .001 & .302 & .403 \\
\hline
\end{tabular}

Notes: $\mathrm{N}=261 ; * * *$ statistical significance at the one-per-cent level; ** at the five-per-cent level; * at the ten-per-cent level; H-L $=\mathrm{Hosmer}$ and Lemeshow test statistic's significance; $C \& S=$ Cox \&Snell R squared; Nagel = Nagelkerke R squared 
